\title{
PERTUMBUHAN DAN PRODUKSI LEGUMINOSA PADA PEMOTONGAN KEDUA YANG DIPUPUK DENGAN BIO SLURRY
}

\author{
Witariadi N.M dan Candraasih K. \\ Fakultas Peternakan ,Universitas Udayana \\ witarimade@yahoo.com
}

\begin{abstract}
ABSTRAK
Penelitian untuk mengetahui pertumbuhan dan produksi leguminosa pada pemotongan kedua yang dipupuk dengan bio slurry. Rancangan yang digunakan adalah Rancangan Acak lengkap (RAL) pola faktorial dengan dua faktor. Jenis tanaman leguminosa yaitu : Centrocema pubescens dan Clitoria ternatea adalah faktor pertama, dan faktor kedua dosis pupuk bio slurry yaitu : tanpa pupuk; bio slurry 10 ton /ha; bio slurry 20 ton /ha; dan bio slurry 30 ton /ha. Variabel yang diamati meliputi: tinggi tanaman, jumlah cabang, jumlah daun, luas daun, berat kering daun, berat kering batang, nisbah berat kering daun dengan berat kering batang, dan berat kering total hijauan. Hasil penelitian menunjukkan bahwa terjadi interaksi antara dosis pupuk dan jenis tanaman leguminosa pada variabel: jumlah cabang, jumlah daun, berat kering daun, berat kering total produksi, dan nisbah berat kering daun dengan berat kering batang. Interaksi ini mengindikasikan bahwa antara faktor dosis pupuk bio slurry dan jenis tanaman leguminosa dapat secara bersama atau sendiri-sendiri dalam mempengaruhi pertumbuhan dan produksi tanaman leguminosa. Meningkatnya dodis bio slurry dapat meningkatkan pertumbuhan dan produksi leguminosa. Disimpulkan bahwa hasil terbaik didapatkan pada jenis leguminosa Clitoria ternatea dengan dosis bio slurry 30 ton/ha.
\end{abstract}

Kata kunci : pertumbuhan, produksi, leguminosa, bio slurry

\begin{abstract}
This study aims at determine the growth and production of legume on the second regrowth fertilized with bio slurry. The study was conducted by using a completely Randomized Design (CRD) with two factors. Legume plants are Centrocema pubescens and Clitoria ternatea are the first factor, and the second factor are dosage of bioslurry fertilizer: 10 tons / ha of bio slurry; 20 tons/ha of bio slurry; and 30 tons/ ha of bio slurry. Variables observed were: plant height, number of branches, number of leaves, leaf area, leaf dry weight, dry weight of stem, leaf stem ratio, and total dry weight of forage. The results showed that there was interaction between fertilizer dosage and legume plant species on variables: number of branches, number of leaves, leaf dry weight, total dry weight of production, and leaf stem ratio. Interaction shows that the growth and production of forage legumes can be influenced by both bio slurry fertilizer and legume species either jointly or individually. Increasing of bio slurry dosage can increase growth and production of legume. It can be concluded that the best results were obtained on Clitoria ternatea with 30 tons/ha dosage of bio slurry.
\end{abstract}

Keywords: growth, production, leguminous, bio slurry

\section{PENDAHULUAN}

Usaha meningkatkan produksi peternakan khususnya ternak ruminansia, perlu disertai dengan peningkatan produksi hijauan pakan ternak baik kualitas maupun kuantitasnya. Hijauan pakan merupakan salah satu bahan makanan ternak yang sangat diperlukan dan besar manfaatnya bagi kehidupan dan kelangsungan populasi ternak. Keberhasilan usaha peternakan khususnya ternak rumininansia sangat tergantung dari ketersedian pakan yang berasal dari hijauan, pendapat ini didukung oleh Soetarno (2003), bahwa hijauan merupakan pakan utama untuk ternak ruminansia dan hijauan sebagai pakan bagi ternak dapat berasal dari rumput, daundaunan, dan sisa-sisa panen berupa jerami.

Alternatif pengadaan hijauan pakan jenis leguminosa sangat baik untuk meningkatkan pertumbuhan dan produksi ternak ruminansia, karena leguminosa dapat menyediakan pakan sepanjang tahun dengan kandungan nutrisi yang cukup tinggi. Jenis leguminosa yang berpotensi dikembangkan adalah Centrocema pubescens dan Clitoria ternatea. Leguminosa ini termasuk tanaman legum yang tahan terhadap kondisi kering, dapat ditanaman pada naungan dan memiliki fungsi sebagai 
tanaman penutup tanah, tanaman sela, dan pencegah erosi. Kesulitan dalam menyediaan hijauan biasanya disebabkan oleh keterbatasan lahan dan semakin menurunnya kesuburan tanah,sehingga perlu untuk meningkatkan kesuburan tanah baik fisik, kimia, maupun biologi melalui pemupukan.

Pemupukan merupakan usaha memberikan tambahan hara ke dalam tanah dengan pupuk anorganik maupun pupuk organik. Sumber pupuk organik dapat berupa kompos, pupuk hijau, pupuk kandang, sisa panen, limbah ternak, limbah industri yang menggunakan bahan pertanian, limbah kota dan limbah biogas (slurry). Melalui teknologi fermentasi (bio slurry) lebih cepat tersedia bagi tanah dan tanaman. Komposisi bio slurry adalah : air 7080\% dan Zat kering $20-30 \%$, jika diuraikan lagi zat kering tersebut mengandung bahan organik 18-27\% (Internasional Training Workshop, 2010). Susanti (2016) penggunaan pupuk bio slurry level 5-15 ton/ ha tidak berpengaruh terhadap pertumbuhan dan produksi Stylosanthes guianensis. Witariadi dan Candraasih (2017) bahwa pemberian bio slurry dosis 30 ton/ha pada tanaman Clitoria ternatea memberikan respon pertumbuhan dan produksi tertinggi pada pemotongan pertama. Arnawa (2014) bahwa penggunaan limbah biogas (slurry) dengan dosis 10-30 ton/ha memberikan pengaruh yang sama terhadap pertumbuhan dan produksi rumput benggala (Panicum maximum cv. Trichoglume).

Berdasarkan informasi diatas pemanfaatan slurry pada tanaman leguminosa sangat terbatas, dimana hasil produktivitasnya hanya pada pemotongan pertama , maka penelitian ini sangat perlu dilaksanakan untuk mengetahui pertumbuhan dan produksi leguminosa pada pemotongan kedua .

\section{MATERI DAN METODE}

\section{Tempat Penelitian}

Percobaan dilaksanakan di rumah kaca di Desa Sading, Badung dan berlangsung selama empat bulan.

\section{Tanah dan Pupuk}

Tanah diambil dari lahan di sekitar rumah kaca ,di Desa Sading,Badung. Slurry diperoleh dari kelompok simantri di Desa Kelating, Tabanan. Tanah dan pupuk sebelum digunakan di analisa di Laboratorium Ilmu Tanah, Fakultas Pertanian, Universitas Udayana (Tabel 1)

\section{Rancangan Percobaan}

Penelitian menggunakan rancangan acak lengkap (RAL) pola faktorial dengan dua faktor. Faktor pertama jenis leguminosa yaitu :Centrosema pubescens dan Clitoria ternatea. Faktor kedua dosis
Tabel 1. Hasil Analisa Tanah, Slurry dan Bio Slurry

\begin{tabular}{clccc}
\hline No & \multicolumn{1}{c}{ Uraian } & Tanah & Slurry & Bio Slurry \\
\hline 1 & $\mathrm{pH}(1: 2,5) \mathrm{H}_{2} \mathrm{O}$ & 6,67 & 6,70 & 6,72 \\
2 & $\mathrm{DHL}(\mathrm{mmhos} / \mathrm{cm})$ & 1,57 & 2,01 & 3,45 \\
3 & C Organik (\%) & 3,12 & 18,65 & 22,48 \\
4 & N Total (\%) & 0,11 & 0,19 & 1,37 \\
5 & P Tersedia (ppm) & 531,88 & 311,25 & 732,45 \\
7 & KTK (me/100g) & 23,93 & - & - \\
8 & Kadar Air : & & & \\
& KU (\%) & 6,83 & 19,69 & 28,22 \\
& KL (\%) & 23,14 & - & - \\
9 & Tekstur : & & & - \\
& Pasir (\%) & 40,22 & - & - \\
& Debu (\%) & 51,14 & - & - \\
& Liat (\%) & 8,65 & - & \\
\hline
\end{tabular}

Keterangan :

$\mathrm{DHL} \quad$ : Daya Hantar Listrik

C Organik : Metode Walkley \& Black

N Total

Kering Udara

Metode Kjelhall

Kapasitas Lapang

$\begin{array}{ll}\text { KU dan KL : } & \text { Metode Graviment } \\ \mathrm{P} & : \text { Posfor } \\ \mathrm{P} & : \text { Metode bray-1 } \\ \mathrm{N} & : \text { Nitrogen } \\ \text { Tekstur } & : \text { Metode Pipet }\end{array}$

pupuk bio slurry yaitu: tanpa pupuk (DO); bio slurry dosis 10 ton/ha(D1); bio slurry dosis 20 ton/ha(D2); dan bio slurry dosis 30 ton/ha (D3). Dari kedua faktor tersebut diperoleh 8 kombinasi perlakuan dan setiap kombinasi perlakuan diulang empat kali, sehingga terdapat 32 pot penelitian.

\section{Variabel yang Diamati}

Variabel yang diamati meliputi : tinggi tanaman (cm); jumlah cabang (batang); jumlah daun (helai); berat kering daun (g); berat kering batang (g); berat kering total hijauan (g); nisbah berat kering daun dengan batang dan luas daun per pot $\left(\mathrm{cm}^{2}\right)$.

\section{Analisa Data}

Data dianalisis dengan sidik ragam, apabila diantara nilai rata-rata perlakuan menunjukkan perbedaan nyata $(\mathrm{P}<0,05)$ maka analisis dilanjutkan dengan uji jarak berganda Duncan (Program SPSS).

\section{HASIL DAN PEMBAHASAN}

Terjadi interaksi antara dosis bio slurry dan jenis tanaman leguminosa terhadap pertumbuhan dan produksi Centrocema pubescens dan Clitoria ternatea (Tabel 2). Interaksi ini mengindikasikan bahwa antara faktor dosis bio slurry dan jenis tanaman leguminosa dapat secara bersama atau sendiri-sendiri dalam mempengaruhi pertumbuhan dan produksi tanaman leguminosa. Data penelitian menunjukkan bahwa semakin meningkat pemakaian dosis pupuk bio slurry (10-30 ton/ha) dapat meningkatkan pertumbuhan dan produksi Centrocema pubescens dan Clitoria ternatea.

Tinggi tanaman leguminosa pada perlakuan tanpa pupuk nyata $(\mathrm{P}<\mathrm{O}, 05)$ tertinggi dibandingkan 
Tabel 2. Pengaruh Dosis Pupuk Bio Slurry terhadap Pertumbuhan Tanaman Leguminosa

\begin{tabular}{|c|c|c|c|c|c|c|c|c|}
\hline \multirow[t]{6}{*}{ Tinggi Tanaman } & \multirow{2}{*}{ Jenis Legum } & \multicolumn{7}{|c|}{ Dosis Pupuk Bio Slurry } \\
\hline & & Do & $\mathrm{D} 1$ & & $\mathrm{D} 2$ & $\mathrm{D}^{2}$ & & Rataan \\
\hline & & \multicolumn{7}{|c|}{....................................... } \\
\hline & $\mathrm{Cp}{ }^{3}$ & $224,25^{1}$ & 196,75 & & 192,50 & 186,25 & & $199,94^{\mathrm{a}}$ \\
\hline & $\mathrm{Ct}$ & 212,50 & 195,25 & & 190,50 & 189.00 & & $196,81^{\mathrm{a}}$ \\
\hline & Rataan & $218,37^{\mathrm{A}}$ & $196,00^{\mathrm{B}}$ & & $191,50^{\mathrm{BC}}$ & $187,63^{C}$ & & \\
\hline \multirow[t]{5}{*}{ Jumlah Cabang } & Jenis Legum & DO & & $\mathrm{D} 1$ & $\mathrm{D} 2$ & & $\mathrm{D}^{2}{ }^{2}$ & Rataan \\
\hline & & \multicolumn{7}{|c|}{ 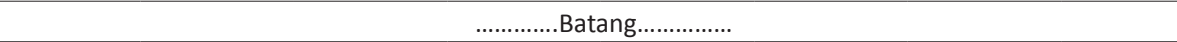 } \\
\hline & $\mathrm{Cp}{ }^{3}$ & $7,75^{\mathrm{c1}}$ & & $9,00^{c}$ & $10,50^{c}$ & & $11,50^{c}$ & $9,69^{b}$ \\
\hline & $\mathrm{Ct}$ & $21,00^{\mathrm{b}}$ & & $28,25^{\mathrm{a}}$ & $29,50^{\mathrm{a}}$ & & $33,25^{a}$ & $28,00^{\mathrm{a}}$ \\
\hline & Rataan & $14,38^{\mathrm{C}}$ & & $18,63^{\mathrm{B}}$ & $20.00^{B}$ & & $22,38^{\mathrm{A}}$ & \\
\hline \multirow[t]{5}{*}{ Jumlah Daun } & Jenis Legum & Do & & D1 & $\mathrm{D} 2$ & & $\mathrm{D}^{2}{ }^{2}$ & Rataan \\
\hline & & \multicolumn{7}{|c|}{ ……….....Helai....................... } \\
\hline & $\mathrm{Cp}{ }^{3}$ & $142,00^{\mathrm{d} 1}$ & & $167.00^{c}$ & $267.00^{b}$ & & $282,50^{b}$ & $214,63^{b}$ \\
\hline & $\mathrm{Ct}$ & $294,75^{b}$ & & $329,25^{a b}$ & $328,25^{a b}$ & & $359,75^{a}$ & $328,00^{\mathrm{a}}$ \\
\hline & Rataan & $218,38^{\mathrm{D}}$ & & $248,13^{C}$ & $297,63^{B}$ & & $321,13^{A}$ & \\
\hline
\end{tabular}

Ket :

1 Nilai dengan huruf kapital berbeda pada kolom atau baris yang sama berbeda nyata $(P<0,05)$ dan nilai dengan huruf kecil yang sama berbeda tidak nyata $(P>0,05)$

2 D0 : Tanpa pupuk (kontrol); D1 : bio slurry dosis 10 ton/ha; D2 : bio slurry dosis 20 ton/ha; dan D3: bio slurry dosis 30 ton/ha

3 Cp: Centrocema pubescens, Ct : Clitoria ternatea

perlakuan lainnya (Tabel 2). Pertumbuhan keatas (vertikal) kemungkinan disebabkan persediaan unsur hara semakin sedikit, sehingga tanaman hanya mampu memanfaatkan unsur hara tersisa untuk pertumbuhan keatas (vertikal) dan belum mampu melakukan pertumbuhan kesamping (horisontal) untuk perbanyakan cabang dan daun. Tanaman yang dipupuk bio slurry menyebabkan ketersedian unsur hara di tanah meningkat, sehingga pertumbuhan tanaman keatas perlahan, karena akan diimbangi dengan pertumbuhan kesamping untuk perbanyakan cabang dan daun. Terlihat pada variabel jumlah cabang dan jumlah daun nyata $(\mathrm{P}<0,05)$ lebih tinggi dibandingkan perlakuan tanpa pupuk. Pupuk bio slurry yang mengalami proses penguraian melalui fermentasi dapat menyediakan unsur hara lebih cepat dan langsung di manfaatkan oleh tanaman untuk pertumbuhan. Witariadi dan Candraasih (2017) bahwa semakin meningkat dosis pupuk bio slurry yang diberikan pada tanaman leguminosa, maka makin tinggi tingkat pertumbuhan tanaman akibat semakin meningkat ketersediaan unsur hara bagi tanaman.

Jumlah cabang dan jumlah daun tanaman leguminosa yang dipupuk bio slurry menunjukkan hasil nyata $(\mathrm{P}<0,05)$ lebih tinggi dibandingkan dengan perlakaun tanpa pupuk (Tabel 2). Dilihat dari hasil analisa pupuk bio slurry menunjukkan kandungan Nitrogen lebih besar (Tabel 1). Nitrogen merupakan unsur hara utama yang dipergunakan oleh tumbuhan untuk pembentukan dan pertumbuhan bagian-bagian vegetatif tanaman seperti : daun, batang dan akar (Sutedjo,2002). Tersedianya unsur hara Nitrogen yang cukup pada tanah, disamping meningkatkan pertumbuhan juga berpengaruh terhadap produksi berat kering tanaman leguminosa menjadi meningkat (Tabel 3).

Berat kering daun, berat kering batang dan total produksi hijauan yang dipupuk bio slurry nyata $(\mathrm{P}<0,05)$ lebih tinggi dibandingkan dengan perlakuan tanpa pupuk (Tabel 3), begitu juga terhadap penampilan karakteristik tumbuh (Tabel 4) memiliki luas daun yang lebih lebar. Luas daun yang lebar memungkinkan tanaman untuk meningkatkan proses fotosintesis. Kapasitas fotosintesis yang berlangsung lebih tinggi, sehingga hasil fotosintesis yang dihasilkan berupa karbohidrat dan protein memberikan hasil maksimal. Hasil dari proses fotosintesis akan disebarkan keseluruh bagian tanaman, sehingga berat kering daun dan batang meningkat. Karbohidrat dan protein merupakan komponen penyusun berat kering tanaman. Budiana (1993) menyatakan bahwa semakin banyak kandungan karbohidrat dan protein dalam tanaman maka berat kering tanaman itu semakin tinggi.

Kandungan C-Organik dan kadar air yang terkandung pada bio slurry lebih tinggi (Tabel 1), hal ini berpengaruh pada hasil luas daun nyata $(\mathrm{P}<0,05)$ lebih tinggi (Tabel 4) pada tanaman leguminosa. Penambahan pupuk organik ke dalam tanah baik berupa kompos maupun pupuk kandang ternyata mengakibatkan peningkatan kadar C-organik tanah. Perbedaan kandungan C-organik tanah adalah sebagai akibat dari perbedaan takaran bahan organik yang diberikan (Umar, 2002). Kadar uap air yang tinggi pada tanah mengakibatkan tanah menjadi lembab, ini berdampak terhadap peningkatan populasi mikroorganisme di dalam tanah berkembang dengan baik dan mampu menguraikan bahan organik lebih cepat sehingga unsur hara yang dibutuhkan oleh 
Tabel 3. Pengaruh Dosis Pupuk Bio Slurry terhadap Produksi Tanaman Leguminosa

\begin{tabular}{|c|c|c|c|c|c|c|}
\hline \multirow{2}{*}{$\begin{array}{l}\text { Berat Kering Total } \\
\text { Hijauan }\end{array}$} & \multirow[t]{2}{*}{ Jenis Legum } & \multicolumn{5}{|c|}{ Dosis Pupuk Bio Slurry } \\
\hline & & Do & $\mathrm{D} 1$ & $\mathrm{D} 2$ & $\mathrm{D}^{2}{ }^{2}$ & Rataan \\
\hline & & \multicolumn{5}{|c|}{ 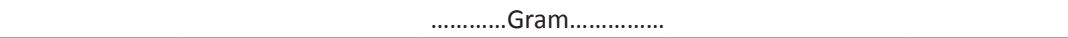 } \\
\hline & $\mathrm{Cp}{ }^{3}$ & $65,72^{\mathrm{e} 1}$ & $74,47^{d}$ & $77,31^{\text {cd }}$ & $85,55^{\mathrm{bcd}}$ & $75,76^{a}$ \\
\hline & $\mathrm{Ct}$ & $66,99^{e}$ & $86,41^{b c}$ & $89,44^{b}$ & $111,51^{\mathrm{a}}$ & $88,58^{a}$ \\
\hline & Rataan & $66,35^{C}$ & $80,44^{\mathrm{B}}$ & $83,37^{\mathrm{B}}$ & $98,53^{A}$ & \\
\hline \multirow{5}{*}{$\begin{array}{l}\text { Berat Kering } \\
\text { Batang }\end{array}$} & Jenis Legum & Do & $\mathrm{D} 1$ & $\mathrm{D} 2$ & $\mathrm{D}^{2}{ }^{2}$ & Rataan \\
\hline & & \multicolumn{5}{|c|}{ 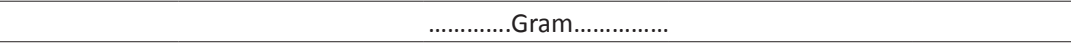 } \\
\hline & $\mathrm{Cp}{ }^{3}$ & $39,81^{1}$ & 40,27 & 41,61 & 46,92 & $42,15^{b}$ \\
\hline & $\mathrm{Ct}$ & 46,13 & 46,28 & 45,79 & 48,09 & $46,57^{a}$ \\
\hline & Rataan & $42,97^{B}$ & $43,27^{B}$ & $43,70^{\mathrm{B}}$ & $47,50^{\mathrm{A}}$ & \\
\hline \multirow{5}{*}{$\begin{array}{l}\text { Berat Kering } \\
\text { Daun }\end{array}$} & Jenis Legum & Do & $\mathrm{D} 1$ & $\mathrm{D} 2$ & $\mathrm{D}^{2}$ & Rataan \\
\hline & & \multicolumn{5}{|c|}{ 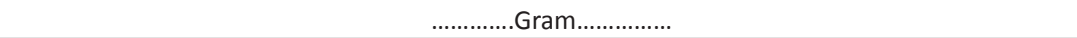 } \\
\hline & $\mathrm{Cp}{ }^{3}$ & $25,92^{\text {cd1 }}$ & $34,20^{b c}$ & $35,70^{b c}$ & $38,63^{b}$ & $33,61^{b}$ \\
\hline & $\mathrm{Ct}$ & $20,86^{d}$ & $40,13^{b}$ & $43,65^{b}$ & $63,42^{\mathrm{a}}$ & $42,02^{a}$ \\
\hline & Rataan & $23,39^{C}$ & $37,17^{B}$ & $39,68^{B}$ & $51,028^{A}$ & \\
\hline
\end{tabular}

Ket :

1 Nilai dengan huruf kapital berbeda pada kolom atau baris yang sama berbeda nyata $(P<0,05)$ dan nilai dengan huruf kecil yang sama berbeda tidak nyata $(P>0,05)$

2 D0 : Tanpa pupuk (kontrol); D1 : bio slurry dosis 10 ton/ha; D2 : bio slurry dosis 20 ton/ha; dan D3: bio slurry dosis 30 ton/ha

3 Cp: Centrocema pubescens, Ct : Clitoria ternatea

Tabel 4. Pengaruh Dosis Pupuk Bio Slurry terhadap Karakteristik Tumbuh Tanaman Leguminosa

\begin{tabular}{|c|c|c|c|c|c|c|}
\hline \multirow[t]{6}{*}{ Luas Daun } & \multirow[t]{3}{*}{ Jenis Legum } & \multicolumn{5}{|c|}{ Dosis Pupuk Bio Slurry } \\
\hline & & Do & $\mathrm{D} 1$ & $\mathrm{D} 2$ & $\mathrm{D}^{2}{ }^{2}$ & Rataan \\
\hline & & \multicolumn{5}{|c|}{$\ldots+\cdots \cdots \cdots$} \\
\hline & $C p^{3}$ & $1483,08^{1}$ & 2322,55 & 2326,86 & 3248,82 & $2345,33^{b}$ \\
\hline & $\mathrm{Ct}$ & 10718,28 & 11739,19 & 11903,60 & 12876,62 & $11809,42^{a}$ \\
\hline & Rataan & $6100,68^{B}$ & $7030,87^{A B}$ & $7115,23^{A B}$ & $8062,72^{A}$ & \\
\hline \multirow{5}{*}{$\begin{array}{l}\text { Nisbah Berat Kering } \\
\text { Daun Dengan Berat } \\
\text { Kering Batang }\end{array}$} & Jenis Legum & Do & D1 & D2 & $\mathrm{D}^{2}{ }^{2}$ & Rataan \\
\hline & & \multicolumn{5}{|c|}{ 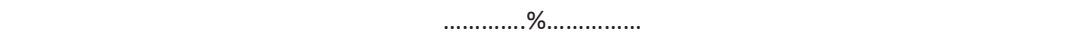 } \\
\hline & $\mathrm{Cp}^{3}$ & $0,65^{\mathrm{d} 1}$ & $0,85^{b c}$ & $0,86^{\mathrm{bc}}$ & $0,82^{b c}$ & $0,80^{\mathrm{a}}$ \\
\hline & $\mathrm{Ct}$ & $0,46^{\mathrm{cd}}$ & $0,88^{b c}$ & $0,95^{\mathrm{b}}$ & $1,32^{\mathrm{a}}$ & $0,90^{\mathrm{a}}$ \\
\hline & Rataan & $0,56^{\mathrm{C}}$ & $0,87^{\mathrm{B}}$ & $0,90^{\mathrm{B}}$ & $1,07^{\mathrm{A}}$ & \\
\hline
\end{tabular}

Ket :

1 Nilai dengan huruf kapital berbeda pada kolom atau baris yang sama berbeda nyata $(P<0,05)$ dan nilai dengan huruf kecil yang sama berbeda tidak nyata $(P>0,05)$

2 D0 : Tanpa pupuk (kontrol); D1 : bio slurry dosis 10 ton/ha; D2 : bio slurry dosis 20 ton/ha; dan D3: bio slurry dosis 30 ton/ha

3 Cp: Centrocema pubescens, Ct : Clitoria ternatea

tanaman tersedia lebih cepat. Pendapat ini didukung (Purwowidodo,1983) bahwa tanah sebagai media pertumbuhan tanaman memberikan pengaruh bagi kelangsungan hidup tanaman, dimana kelembaban tanah memegang peranan yang sangat penting dalam proses metabolisme mikroba dan secara tidak langsung berpengaruh terhadap suplay oksigen.

Nisbah berat kering daun dengan berat kering batang tanaman leguminosa yang dipupuk bio slurry nyata $(\mathrm{P}<0,05)$ lebih tinggi dibandingkan dengan perlakuan tanpa pupuk (Tabel 4). Tanaman leguminosa memiliki kualitas baik, apabila memberikan nilai nisbah berat kering daun dan berat kering batang yang tinggi. Persentase berat kering daun (Tabel 4) lebih tinggi pada tanaman leguminosa yang dipupuk dengan bio slurry, menyebabkan kandungan karbohidrat dan proteinnya semakin tinggi, akan tetapi bila tanaman memiliki persentase berat kering batang yang lebih besar dari persentase berat kering daun, maka leguminosa tersebut kualitasnya rendah, karena kandungan serat kasar yang terbentuk akan semakin tinggi.

Jenis tanaman leguminosa (Centrocema pubescens dan Clitoria ternatea) bahwa leguminosa jenis Clitoria ternatea memberikan hasil nyata $(\mathrm{P}<0,05)$ lebih tinggi dibandingkan jenis Centrocema pubescens. Leguminosa jenis Clitoria ternatea lebih mampu memanfaatkan unsur hara yang tersedia di dalam tanah untuk meningkatkan pertumbuhan dan produksi. Kandungan unsur hara Nitrogen yang lebih tinggi pada bio slurry dimanfaatkan oleh tanaman untuk memperbanyak pertumbuhan cabang dan daun. Leguminosa Clitoria ternatea merupakan tumbuhan yang merambat, cepat tumbuh cabang dan pertumbuhan daun yang banyak. Untuk mendapatkan produksi maksimal tanaman Clitoria ternate dibuatkan penyangga, sehingga tanaman bisa merambat. Pada bagian teratas dari penyangga akan tumbuh cabang dan bergerombol dengan jumlah daun yang banyak. Berbeda dengan jenis leguminosa Centrocema pubescens, dimana cara tumbuhnya membelit dan menjalar, akibatnya pertumbuhan 
batang terus memajang tanpa diimbangi pertumbuhan daun,sehingga produksinya menjadi rendah.

\section{SIMPULAN}

Berdasarkan hasil penelitian dapat disimpulkan bahwa terjadi interaksi antara faktor dosis bio slurry dengan jenis tanaman leguminosa. Dosis bio slurry 30 ton/ha pada jenis leguminosa Clitoria ternatea memberikan pertumbuhan dan produksi paling baik pada pemotongan kedua.

\section{UCAPAN TERIMAKASIH}

Terimakasih disampaikan kepada Universitas Udayana melalui Lembaga Penelitian dan Pengabdian kepada masyarakat atas dana yang diberikan melalui DIPA PNBP Universitas Udayana.

\section{DAFTAR PUSTAKA}

Arnawa,I.W. 2014. Pertumbuhan dan Produksi Rumput Benggala (Panicum Maximum cv.Trchoglume) yang diberi pupuk organik dengan dosis berbeda,
Skripsi Fakultas Peternkan Universitas Udayana, Denpasar.`

Budiana.1993. Produksi Tanaman Hijauan Pakan Ternak Tropik. Fakultas Peternakan, Universitas Gajah Mada, Yogyakarta.

Internasional Training Workshop. 2010.Training Material of Biogas Technology.Yunan Normal University Yunan,China. P 102

Purwowidodo.1983. Tehnologi Mulsa. Jakarta. dewaruci Press.

Rita N.S. 2016.Pertumbuhan dan Produksi Hijauan Stylosanthes guianensis pada Berbagai Level Aplikasi Pupuk Bio slurry. E-Journal Peternakan Tropika, Vol. 4, No.1 Tahun 2016, hal.267-282.

Soetarno, T. 2003. Manajemen Budidaya Ternak Perah. Laboratorium Ternak Perah. Fakultas Peternakan Universitas Gadjah Mada. Yogyakarta. Sutedjo, M M. 2002. Pupuk dan Cara Pemupukan. Penerbit Rineka Cipta, Jakarta.

Witariadi,N.M., dan Candraasih.K. 2017. Produktivitas Tanaman Leguminosa (Centrocema pubescens dan Clitoria ternatea) yang Dipupuk dengan Pupuk Bio Slurry.Majalah Ilmiah Peternakan, ISSN: 0853-8999, Vol.20, No. 3, Tahun 2017. 